\title{
Ground magnetic investigations of selected aeromagnetic anomalies in southern West Greenland
}

\section{B. S. Mielby and F. Svendsen}

Ground magnetic investigations were carried out during the summer of 1978 to elucidate some prominent aeromagnetic anomalies (Thorning, 1976, 1977).

Four different areas were visited (Thorning, this report, fig. 23), additional reconnaissance work being carried out for Leif Thorning on the Taserssuaq granodiorite north of Godthåbsfjord (Thorning, this report). During the field work, total field magnetic profiles were obtained using a proton magnetometer (Geometrics G-816) and in situ susceptibilities were measured with an ABEM Kappameter KT-3.
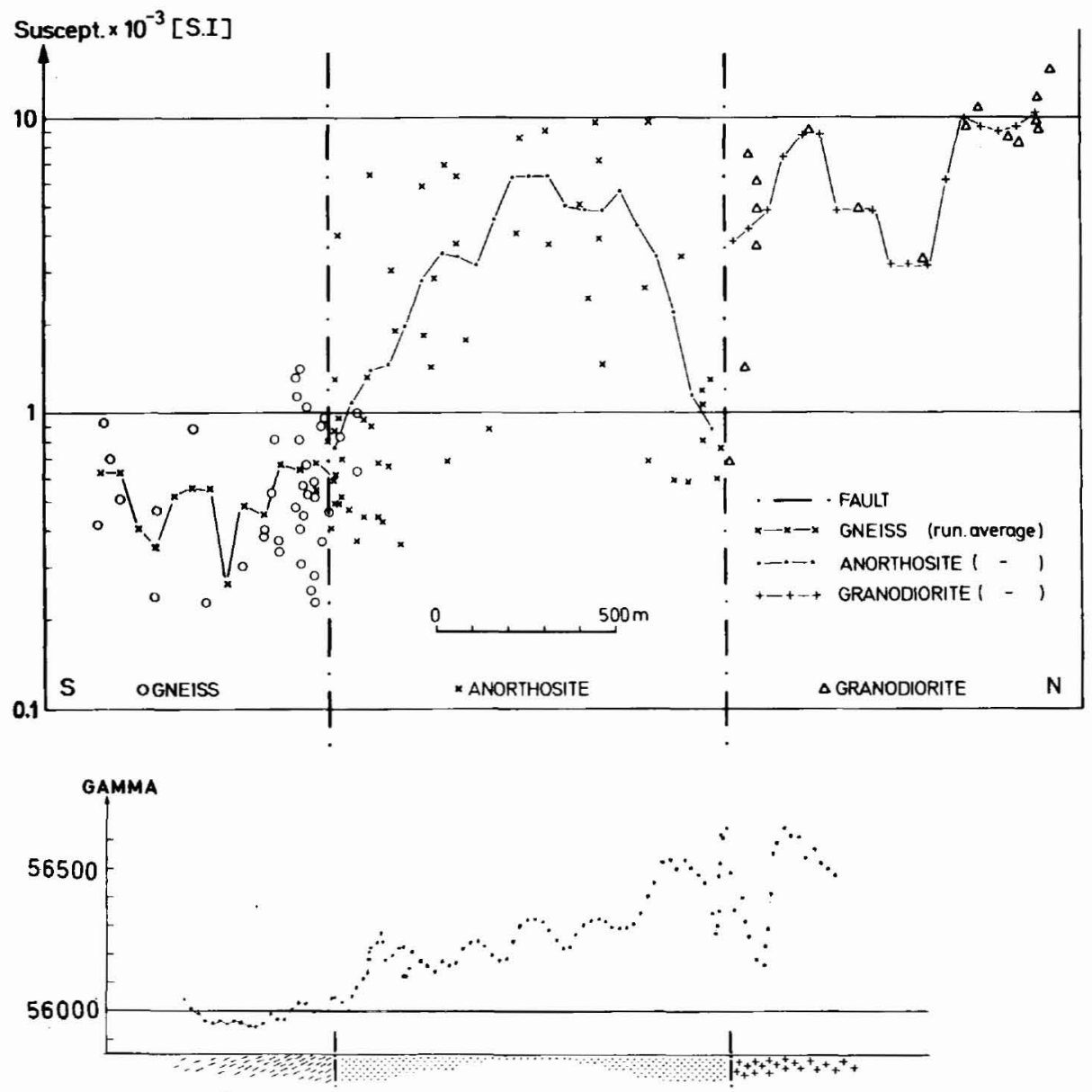

Fig. 24. Summary of results from Ilulialik. The susceptibility is projected into the direction of the magnetic profile. 


\section{Isuitsup kûa}

The Majorqaq anomaly minimum to the south of the maximum noted in 1977 (Thorning et al., 1978) was studied.

Severe snow conditions made magnetic profiling almost impossible, and thus the work consisted mainly of in situ susceptibility measurements which will be compiled with the 1977 data.

\section{Ilulialik}

Magnetic properties of the rocks in proximity of the faults (Allaart et al., 1977) were investigated. Four profiles (750-2500 $\mathrm{m}$ in length), normal to the known faults, were measured together with susceptibilities at approximately 120 localities. Total magnetic field and susceptibility profiles correspond (fig. 24), both parameters increasing south to north, from gneiss through anorthosite to granodiorite. Local anomalies in the magnetic field occur close to faults and these may be related to the degree of mylonitization. This is in accordance with the susceptibility measurements.

\section{Ivisârtoq}

The isolated, sharp aeromagnetic anomaly which exists in connection with supracrustal rocks and the magnetic properties north and south of this were investigated. A magnetic

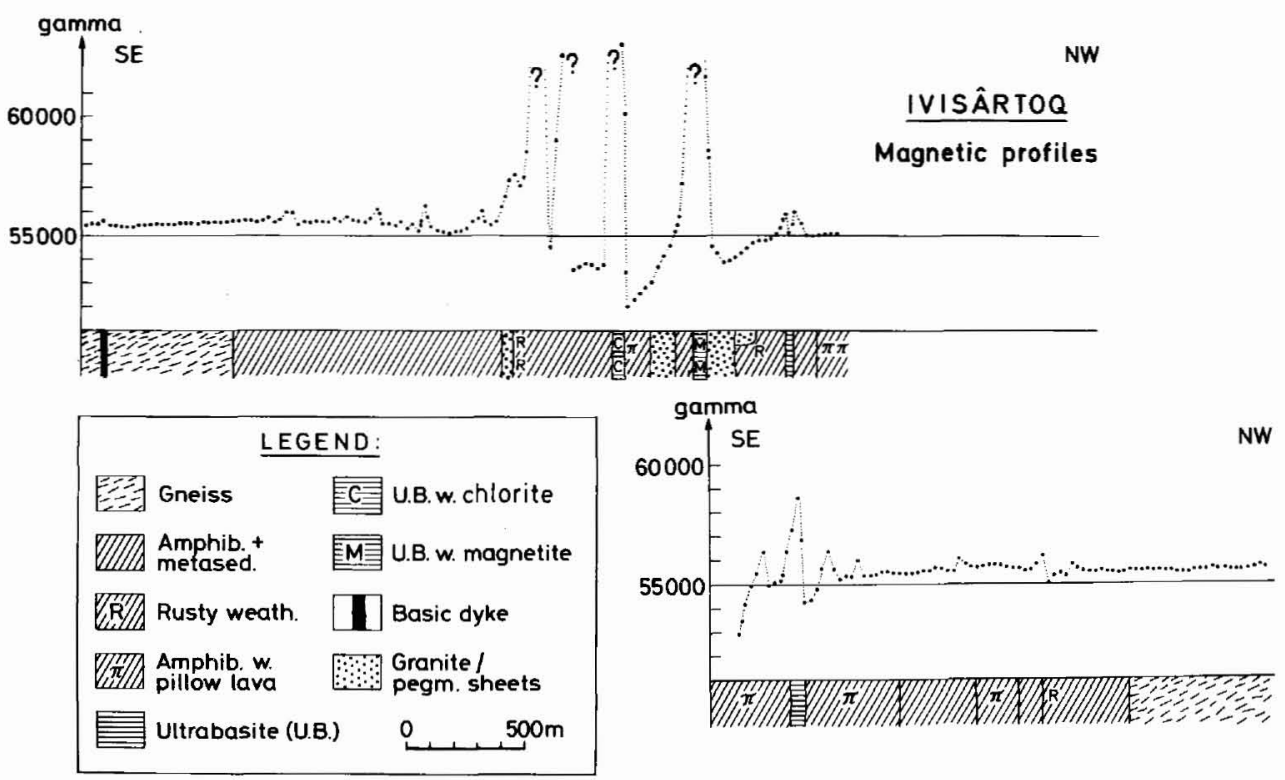

Fig. 25. Summary of results from Ivisârtoq. The two magnetic profiles have the same strike but are offset with respect to one another. The rock unit at the NW end of the upper profile is the same as that at the SE end of the lower profile. The question marks in the figure indicate that the gradient in the magnetic field is too large for the magnetometer to measure. 
Table 5. Statistical analysis of susceptibility data from Ivisârtoq

\begin{tabular}{lccrr}
\hline Rock type & $\begin{array}{c}\bar{x} \times 10^{-3} \\
(\text { SI units) }\end{array}$ & $\begin{array}{c}\text { Range } \times 10^{-3} \\
\text { (SI units) }\end{array}$ & N \\
\hline Group I & & & & \\
Nûk gneiss & 3.51 & $0.65-$ & 6.35 & 15 \\
Amphibolite & 2.23 & $0.72-25.30$ & 26 \\
Pillow Lava & 1.17 & $0.72-$ & 1.72 & 9 \\
Rusty zones & 0.92 & $0.46-$ & 1.27 & 3 \\
Granite/Pegmatite & 0.57 & $0.22-$ & 0.96 & 12 \\
\hline Group II & & & & \\
Amphib. (+ magnetite) & $\$ 31.48$ & $86.09-161.20$ & 3 \\
U1trabasite (U.B.) & 55.15 & $33.22-92.85$ & 4 \\
U.B. (+ chlorite) & 250.22 & $212.00-285.13$ & 4 \\
U.B. (+ magnetite) & 392.56 & $392.56-737.25$ & 3 \\
\hline $\bar{x}=$ Arithmetic mean & & & & \\
$N=$ Number of localities & & & &
\end{tabular}

profile normal to the trend of structure and the aeromagnetic anomaly and susceptibilities at 75 localities were measured. The profile covers the whole sequence of supracrustal rocks and adjacent gneisses (Friend \& Hall, 1977), but due to the effects of the topography an offset was made. The rocks were divided into nine groups, based on units shown on the geological maps and on the results of the measurements. Oriented samples were taken from eight of these groups.

The results of the investigations are shown in fig. 25 and Table 5. The different rock types may be divided into two main groups (Table 5), with susceptibilities less than and greater than $10 \times 10^{-3}$ (S. I. units).

The first group gives total field magnetic values consistently between 55000 and 56000 gamma, whereas the second group gives pronounced peaks. Magnetite-bearing ultrabasite, ultrabasite with chlorite and some amphibolite introduce gradients affecting the reliability of the proton magnetometer (fig. 25). The aeromagnetic anomaly corresponds with the distribution of these rock types. North and south of the anomaly-causing bodies magnetic properties of rocks were similar.

\section{Nordlandet}

Oriented samples were collected for petrological and magnetic investigation. Susceptibility measurements and oriented samples were collected at about 30 localities. Weathering of the rocks made it difficult to identify the different rock types in the field, and presentation of results must await further examination in the laboratory.

\section{References}

Allaart, J. H., Jensen, S. B., McGregor, V. R. \& Walton, B. J. 1977: Reconnaissance mapping for the 1:500 000 map sheet in the Godthåb-Isua region, southern West Greenland. Rapp. Gronlands geol. Unders. 85, 50-54.

Friend, C. R. L. \& Hall, R. P. 1977: Field work in the Ivisârtoq area, inner Godthåbsfjord, southern West Greenland. Rapp. Grønlands geol. Unders. 85, 54-60. 
Thorning, L. 1976: Aeromagnetic surveys in southern and central West Greenland between $63^{\circ}$ and $71^{\circ}$ N. Rapp. Grønlands geol. Unders. 80, 61-65.

Thorning, L. 1977: Continuation of the aeromagnetic surveys in southern and central West Greenland between $64^{\circ}$ and $72^{\circ}$ N. Rapp. Grønlands geol. Unders. 85, 34-37.

Thorning, L., Jensen, L. B., Marcussen, C., Mielby, B. S. \& Petersen, S. A. 1978: Geophysical field work on selected aeromagnetic anomalies in central West Greenland. Rapp. Grønlands geol. Unders. 90, 38-42.

Laboratoriet for Geofysik, Geologisk Institut, Aarhus University, Finlandsgade 6, DK-8200 Arhus $N$.

\title{
International field work on Archaean gneisses in the Godthåbsfjord-Isua area, southern West Greenland
}

\author{
D. Bridgwater, J. H. Allaart, H. Baadsgaard, K. D. Collerson, I. Ermanovics, \\ B. E. Gorman, W. Griffin, G. Hanson, V. R. McGregor, S. Moorbath, \\ A. P. Nutman, P. Taylor, E. Tveten and J. Watson
}

Geoscientists representing the main research institutes who discovered and have made significant contributions to our understanding of the early crustal rocks in the North Atlantic area visited West Greenland in June 1978. The group was partially financed by Nato scientific research grant 949 and by national research organisations, universities and geological surveys in Denmark, Norway, the United Kingdom, Canada and the USA. Bridgwater, Taylor and Moorbath stayed on into July at Isua where they joined a party financed by the U.S. S.N.F. organised by C. Ponnamperuma (University of Maryland.

The field work had four main objectives.

(1) To allow scientists working in adjacent ancient shield areas in Norway, Scotland and Labrador to discuss field methods of distinguishing rock units in high grade metamorphic areas with field geologists working in Greenland.

(2) To allow discussion on the outcrop between field and laboratory based scientists in an attempt to resolve differences in interpretation.

(3) To discuss the most important problems for further research and to make collections for laboratory work.

(4) To check field evidence used to show the order of geological events and to identify various lithological units. This was particularly important in the Isua area where there has been debate both about relations between the major rock units and about the primary character of many of the highly deformed rocks within the supracrustal succession. 